\title{
An Experimental Study of Fan Inflow Distortion Tone Noise
}

\author{
L. Danielle Koch
}

Glenn Research Center, Cleveland, Ohio 


\section{NASA STI Program . . . in Profile}

Since its founding, NASA has been dedicated to the advancement of aeronautics and space science. The NASA Scientific and Technical Information (STI) program plays a key part in helping NASA maintain this important role.

The NASA STI Program operates under the auspices of the Agency Chief Information Officer. It collects, organizes, provides for archiving, and disseminates NASA's STI. The NASA STI program provides access to the NASA Aeronautics and Space Database and its public interface, the NASA Technical Reports Server, thus providing one of the largest collections of aeronautical and space science STI in the world. Results are published in both non-NASA channels and by NASA in the NASA STI Report Series, which includes the following report types:

- TECHNICAL PUBLICATION. Reports of completed research or a major significant phase of research that present the results of NASA programs and include extensive data or theoretical analysis. Includes compilations of significant scientific and technical data and information deemed to be of continuing reference value. NASA counterpart of peer-reviewed formal professional papers but has less stringent limitations on manuscript length and extent of graphic presentations.

- TECHNICAL MEMORANDUM. Scientific and technical findings that are preliminary or of specialized interest, e.g., quick release reports, working papers, and bibliographies that contain minimal annotation. Does not contain extensive analysis.

- CONTRACTOR REPORT. Scientific and technical findings by NASA-sponsored contractors and grantees.
- CONFERENCE PUBLICATION. Collected papers from scientific and technical conferences, symposia, seminars, or other meetings sponsored or cosponsored by NASA.

- SPECIAL PUBLICATION. Scientific, technical, or historical information from NASA programs, projects, and missions, often concerned with subjects having substantial public interest.

- TECHNICAL TRANSLATION. Englishlanguage translations of foreign scientific and technical material pertinent to NASA's mission.

Specialized services also include creating custom thesauri, building customized databases, organizing and publishing research results.

For more information about the NASA STI program, see the following:

- Access the NASA STI program home page at http://www.sti.nasa.gov

- E-mail your question via the Internet to help@ sti.nasa.gov

- Fax your question to the NASA STI Help Desk at 443-757-5803

- Telephone the NASA STI Help Desk at 443-757-5802

- Write to: NASA Center for AeroSpace Information (CASI) 7115 Standard Drive Hanover, MD 21076-1320 
NASA/TM-2010-215844

\section{An Experimental Study of Fan Inflow Distortion Tone Noise}

L. Danielle Koch

Glenn Research Center, Cleveland, Ohio

Prepared for the

15th Aeroacoustics Conference (30th Aeroacoustics Conference)

sponsored by the American Institute of Aeronautics and Astronautics and Council of European Aerospace Societies

Miami, Florida, May 11-13, 2009

National Aeronautics and

Space Administration

Glenn Research Center

Cleveland, Ohio 44135 


\section{Acknowledgments}

I sincerely appreciate the patient guidance of Ed Envia and Dan Sutliff throughout the course of this work. I would also like to thank Joel Lauer, Ray Loew, and the team at the AeroAcoustic Propulsion Laboratory for making the experiment a reality. This work was supported by the NASA Fundamental Aeronautics Program, Subsonic Fixed Wing Project in the area of noise reduction.

This work was sponsored by the Fundamental Aeronautics Program at the NASA Glenn Research Center.

Level of Review: This material has been technically reviewed by technical management.

Available from

NASA Center for Aerospace Information 7115 Standard Drive

Hanover, MD 21076-1320
National Technical Information Service 5285 Port Royal Road Springfield, VA 22161 


\title{
An Experimental Study of Fan Inflow Distortion Tone Noise
}

\author{
L. Danielle Koch \\ National Aeronautics and Space Administration \\ Glenn Research Center \\ Cleveland, Ohio 44135
}

\begin{abstract}
The tone noise generated when a fan ingests circumferentially distorted flow was studied by an experiment conducted with the Advanced Noise Control Fan at the NASA Glenn Research Center. The inflow was distorted by inserting cylindrical rods radially into the duct. The rods were arranged in circumferentially irregular patterns in three of the five configurations tested. Rods were held in place using a mounting ring with 30 equally spaced holes placed at an axial location one rotor chordlength upstream of the fan. Acoustic pressure was measured in the inlet and exhaust duct of the fan using the Rotating Rake fan tone measurement system. Sound power levels, calculated from the measured data, were plotted as a function of circumferential mode. An analytic description of the unsteady pressure distribution at the interaction plane between the stationary rods and the fan rotor is presented in a form suitable for representing the circumferentially irregularly placed rods. Terms in the analytical description for sound power were proven to be useful in determining the dominant circumferential modes measured in the experiment and the differences in mode power level between the configurations tested. Insight gained through this work will be useful in the development of tools to compute fan inflow distortion tone noise.
\end{abstract}

\section{Nomenclature}

$a$

$a_{m n_{\mu}}$

$A_{m n \mu}$

$a_{m, n}$

$B$

$c_{m, n}$

$C_{m, n}$

$d$

$f$

$i$

$j$

$k$

$M$

$m$ speed of sound

axial direction of cosine of $m, \mu$ wave, $n^{\text {th }}$ harmonic, $=\sqrt{1-1 / \xi_{m n \mu}{ }^{2}}$

power-effective area for $m, \mu$ mode, $n^{\text {th }}$ harmonic

direction cosine of $n^{\text {th }}$-harmonic, $m$-lobe mode, $=\sqrt{1-1 / \xi_{m n}{ }^{2}}$

number of rotor blades

amplitude of $n^{\text {th }}$ harmonic, $m^{\text {th }}$ mode due to rotor interaction with single vane

amplitude of $n^{\text {th }}$ harmonic, $m^{\text {th }}$ mode due to rotor interaction with stator assembly

rod diameter, $\mathrm{ft}$

frequency, cps

$\sqrt{-1}$, also used as index

index

index

bulk inlet Mach number

circumferential mode index 


\begin{tabular}{|c|c|}
\hline$n$ & harmonic index \\
\hline$N$ & rotor shaft speed, revolutions/sec \\
\hline$p$ & local duct pressure due to rotor interaction with stator assembly \\
\hline$p^{\prime}$ & local duct pressure due to rotor interaction with single stator vane \\
\hline$q$ & stator vane index \\
\hline $\operatorname{Re}$ & real part of operand \\
\hline $\mathrm{St}$ & Strouhal number, $\frac{\omega d}{2 \pi M a}$ \\
\hline$t$ & time coordinate \\
\hline$U$ & normalized power, $=\sum_{n} \sum_{m} a_{m n}\left|\frac{C_{m n}}{c_{m n}}\right|^{2}$ \\
\hline$V$ & number of stator vanes \\
\hline$W$ & acoustic power \\
\hline$W^{\prime}$ & approximation for acoustic power \\
\hline$\beta_{q}$ & $(n B-m) \Delta \theta_{q}$ \\
\hline$\beta_{q j}$ & $\beta_{q}-\beta_{j}$ \\
\hline$\theta$ & pressure field angular coordinate \\
\hline$\phi_{m n}$ & phase of $m^{\text {th }}$ mode \\
\hline$\mu$ & radial mode index \\
\hline$\xi_{m n \mu}$ & cutoff ratio of $m, \mu$ mode, $n^{\text {th }}$ harmonic \\
\hline$\xi_{m n}$ & cutoff ratio of $m$-lobe mode, $n^{\text {th }}$ harmonic \\
\hline$\omega$ & circular frequency, $\omega=2 \pi f$ \\
\hline$\Omega$ & rotor shaft angular velocity \\
\hline$*$ & complex conjugate \\
\hline
\end{tabular}

\section{Introduction}

Meeting the growing demand for air transportation poses challenges to aircraft engine manufacturers and airlines. As our airports operate closer to their maximum capacity and more stringent community noise limits are imposed, it becomes more important to design quieter aircraft and follow operational procedures designed to reduce noise exposure in surrounding neighborhoods (Refs. 2 and 3). Fans have been known to be a dominant source of aircraft engine noise. Progress has been made in measuring, predicting, and reducing tones generated by rotor-stator interaction, which is an important contributor to total fan noise emissions (Ref. 4). Less attention has been given to understanding the noise generated by fans ingesting circumferentially non-uniform flow. This is an area of concern for those who are conceptualizing the next generation of quiet commercial aircraft that may use embedded engines (Ref. 5).

How can we predict tones produced by a fan ingesting distorted inflow? To begin to answer this question, an experiment has been conducted at the NASA Glenn Research Center using the Advanced Noise Control Fan (ANCF). The purpose of the test was to measure the tone noise produced by the rotor 
blades when the inflow was distorted by a set of rods placed upstream of the rotor in circumferentially irregular patterns. Measurements of the acoustic pressures in the inlet and exhaust duct were obtained from the Rotating Rake are presented here.

In order to explain features of the measurements, Sofrin and Mathews' (Ref. 1) analytical description of acoustic pressure at the interaction plane was recast in a form suitable for representing the circumferentially irregularly placed rods that were tested. Terms in the analytic sound power expression were proven to be useful in predicting the dominant modes measured in the experiment and the differences in sound power levels between the configurations tested.

\section{Experiment}

The experiment was conducted using the NASA Glenn Advanced Noise Control Fan that is housed within AeroAcoustic Propulsion Laboratory (AAPL). The AeroAcoustic Propulsion Laboratory (Ref. 6) is a $39.6 \mathrm{~m}(130 \mathrm{ft})$ diameter geodesic dome that serves to both minimize testing noise heard by neighboring communities and provide an anechoic (above $125 \mathrm{~Hz}$ ) environment for fan and jet noise research.

ANCF, shown in Figure 1, is a modified commercial ventilation fan valued for being highly configurable and proven to be useful in furthering our understanding of fan and duct acoustics and noise control techniques. Originally built in the early 1990s, the fan has been primarily used in the investigation of rotor-stator interaction. Data from these experiments are often used to validate noise prediction codes under development (Ref. 7).

The ANCF is approximately $1.2 \mathrm{~m}$ (48 in.) in diameter and the centerline of the rig is $3.0 \mathrm{~m} \mathrm{(10} \mathrm{ft)}$ above the floor. For these tests, no stator vanes were installed downstream of the rotor. The rotor had 16 blades (Ref. 8) set at a $28^{\circ}$ pitch angle for all test conditions. (The coordinates for the blades are available upon request.) A nominal rotor blade tip clearance gap of $0.7 \mathrm{~mm}(0.03 \mathrm{in}$.) is made possible by the use of an abradable material built into the rotor shroud.

An Inflow Control Device (ICD) is used to condition the flow entering the fan, removing large-scale turbulence and ground vortices. The ICD, shown in Figures 1 and 2, has 20 thin metal ribs and is constructed from $0.61 \mathrm{~m}$ ( 2 in.) thick metal honeycomb. Hub diameter was $0.46 \mathrm{~m}$ (18 in.) at the fan leading edge yielding a rotor hub-to-tip ratio, $\sigma=0.375$. The inlet plane was located $0.92 \mathrm{~m} \mathrm{(36.2} \mathrm{in.)} \mathrm{or}$ approximately $0.75 \mathrm{~L} / \mathrm{D}$ ahead of the leading edge of the fan at the tip location. The exhaust plane was located $1.2 \mathrm{~m}$ (45.44 in.) or approximately 1.0 L/D downstream of the trailing edge of the fan at the tip location. Downstream of the test section, centerbody diameter increases to $0.71 \mathrm{~m}(24 \mathrm{in}$.) to provide the necessary nozzle area contraction, yielding a hub-to-tip ratio, $\sigma=0.500$.

The inflow to the rotor was distorted by installing smooth-surfaced cylindrical rods upstream of the rotor. Four distortion patterns were tested, as shown in Figure 3, using the 30-rod ring. The circumferential positions of the rods for the various configurations are given in Table 1. Angles indicated are referenced to the center of the circumferential slot cut through the shroud for hot wire probe access for aerodynamic measurements not reported here. Angles indicated on Figure 3 increase from top dead center in the clockwise direction, aft looking forward. The rods were $1.27 \mathrm{~cm}(0.5 \mathrm{in}$.) in diameter and were $31.75 \mathrm{~cm}$ (12.5 in.) long, resulting in a $6.35 \mathrm{~cm}$ ( 2.5 in.) gap between the bottom of the rods and the rotor hub. The centerline of the rods was $14.29 \mathrm{~cm}$ (5.625 in.) upstream of the rotor leading edge at the tip, or approximately one rotor chord length upstream. Unused holes in the rod-mounting ring were covered with aluminum tape during testing.

Upgraded in 2007 , the rotor is driven by a $200 \mathrm{hp}$ motor and speed is controllable within $\pm 2 \mathrm{rpm}$. Rotor speed can vary from 0 to $2500 \mathrm{rpm}$ and is detected by a 128 pulse/rev optical quadrature encoder. Direction of rotation is counterclockwise, forward looking aft. Data was recorded at three speed settings given in Table 2. 
TABLE 1.-ANGULAR POSITIONS OF RODS

\begin{tabular}{|c|c|l|}
\hline Configuration & Rods & \multicolumn{1}{|c|}{ Rod circumferential locations } \\
\hline 1 & 6 & $0^{\circ}, 60^{\circ}, 120^{\circ}, 180^{\circ}, 240^{\circ}, 300^{\circ}$ \\
\hline 2 & 6 & $0^{\circ}, 12^{\circ}, 24^{\circ}, 36^{\circ}, 336^{\circ}, 348^{\circ}$ \\
\hline 3 & 15 & $0^{\circ}, 12^{\circ}, 24^{\circ}, 36^{\circ}, 48^{\circ}, 60^{\circ}, 72^{\circ}, 84^{\circ}, 276^{\circ}, 288^{\circ}, 300^{\circ}, 312^{\circ}, 324^{\circ}, 336^{\circ}, 348^{\circ}$ \\
\hline 4 & 8 & $0^{\circ}, 12^{\circ}, 24^{\circ}, 108^{\circ}, 120^{\circ}, 192^{\circ}, 216^{\circ}, 348^{\circ}$ \\
\hline 5 & 0 & N/A \\
\hline
\end{tabular}

TABLE 2.-TEST CONDITIONS

\begin{tabular}{|c|c|c|c|}
\hline $\begin{array}{c}\text { Rotor rotational speed, } \\
\mathrm{rpm}\end{array}$ & $\begin{array}{c}\text { Rotor tip speed } \\
\mathrm{m} / \mathrm{s}(\mathrm{ft} / \mathrm{s})\end{array}$ & $\begin{array}{c}\text { Rotor BPF, } \\
\mathrm{Hz}\end{array}$ & $\begin{array}{c}\text { Bulk inlet } \\
\text { Mach number }\end{array}$ \\
\hline 1400 & $89(293)$ & 373 & 0.11 \\
\hline 1800 & $115(377)$ & 480 & 0.14 \\
\hline 2000 & $128(419)$ & 533 & 0.15 \\
\hline
\end{tabular}

Two 15-microphone arrays were used to record the farfield sound distribution from the Advanced Noise Control Fan. The origin of the inlet microphone array was at the centerline of the inlet plane, and the origin of the exhaust array was at the centerline of the exit plane. The $0^{\circ}$ and $180^{\circ}$ position of the farfield microphones are indicated on Figure 2. Microphones were placed $3.7 \mathrm{~m}(12 \mathrm{ft})$ from their respective origins. Angular locations for the microphones are given in Table 3. Farfield microphone measurements were acquired synchronously with shaft speed at a rate of 256 samples per revolution, which allows for analysis up to the $128^{\text {th }}$ harmonic of the shaft frequency, or equivalently, up to the $8^{\text {th }}$ harmonic of the blade passing frequency (BPF) for this test (Ref. 7).

In-duct acoustic pressure measurements upstream and downstream of the rotor were also acquired with the Rotating Rake (Ref. 9). The Rotating Rake system is a continuously rotating radial microphone rake that is inserted into the duct, generally at either the inlet entrance or exhaust exit plane. The system utilizes spinning mode theory and Doppler-shift physics to separate circumferential modes and the cylindrical wave equation solution to reduce the radial modes. It provides a complete map of the acoustic duct modal magnitudes and phases present in the fan duct. Details of the operation and data reduction are presented in Reference 9.

TABLE 3.-FARFIELD MICROPHONE LOCATIONS

\begin{tabular}{|c|c|c|}
\hline $\begin{array}{c}\text { Microphone } \\
\text { number }\end{array}$ & $\begin{array}{c}\text { Inlet microphone } \\
\text { array locations, } \\
\text { deg. }\end{array}$ & $\begin{array}{c}\text { Exhaust microphone } \\
\text { array locations, } \\
\text { deg. }\end{array}$ \\
\hline 1 & 0.0 & 90.0 \\
\hline 2 & 6.4 & 95.0 \\
\hline 3 & 12.9 & 100.0 \\
\hline 4 & 19.3 & 105.0 \\
\hline 5 & 25.7 & 110.0 \\
\hline 6 & 32.1 & 115.0 \\
\hline 7 & 38.6 & 120.0 \\
\hline 8 & 45.0 & 125.0 \\
\hline 9 & 51.4 & 130.0 \\
\hline 10 & 57.9 & 135.0 \\
\hline 11 & 64.3 & 140.0 \\
\hline 12 & 70.7 & 145.0 \\
\hline 13 & 77.1 & 150.0 \\
\hline 14 & 83.6 & 155.0 \\
\hline 15 & 90.0 & 160.0 \\
\hline & & \\
\hline
\end{tabular}




\section{Analysis}

In their paper, Tyler and Sofrin (Ref. 10) analytically described the unsteady pressure distribution at the interaction plane between a rotor and stator. In their formulation, the blades and vanes were idealized by assuming equal circumferential spacing. Later, while investigating tones present in cut-off fan stage designs, Sofrin and Mathews (Ref. 1) analytically described the pressure distribution at the interaction plane between a rotor and a stator, assuming the stator vane circumferential locations deviated a small amount from uniform spacing. The present work extends Sofrin and Mathews' (Ref. 1) relations in a form more convenient for representing irregularly spaced vanes without the small deviation angle assumption.

Beginning with Sofrin and Mathews' (Ref. 1) description of the pressure field at a radial and axial location in a duct resulting from the interaction of a rotor and a single vane, we have

$$
p^{\prime}(\theta, t)=\sum_{n=1}^{\infty} \sum_{m=-\infty}^{\infty} c_{m n} \cos \left(m \theta-n \omega t+\phi_{m n}\right)=\operatorname{Re} \sum_{n=1}^{\infty} \sum_{m=-\infty}^{\infty} c_{m n} \exp i\left(m \theta-n \omega t+\phi_{m n}\right)
$$

Recognizing that the complete pressure field is found by the superposition of the effects of $V$ vanes located at varying angular distances from the reference vane we have

$$
\begin{gathered}
p(\theta, t)=\sum_{n=1}^{\infty} \sum_{m=-\infty}^{\infty} \sum_{q=0}^{V-1} c_{m n} \cos \left(m\left(\theta-\Delta \theta_{q}\right)-n \omega\left(t-\Delta t_{q}\right)+\phi_{m n}\right) \\
\omega=2 \pi f=2 \pi B N=B \Omega \\
\Delta t_{q}=\frac{\Delta \theta_{q}}{\Omega} \\
\Delta \theta_{q}=\frac{2 \pi q}{V} \text { for stators with } V \text { equally spaced vanes } \\
\Delta \theta_{q}=\Delta \theta_{q} \text { for stators with } V \text { irregularly spaced vanes } \\
p(\theta, t)=\sum_{n=1}^{\infty} \sum_{m=-\infty}^{\infty} \sum_{q=0}^{V-1} c_{m n} \cos \left(m \theta-n \omega+\phi_{m n}-m \Delta \theta_{q}+n B \Delta \theta_{q}\right) \\
\left.p(\theta, t)=\sum_{n=1}^{\infty} \sum_{m=-\infty}^{\infty} \sum_{q=0}^{V-1} c_{m n} \exp i\left(m \theta-n \omega+\phi_{m n}\right) \exp i\left[(n B-m) \Delta \theta_{q}\right)\right]
\end{gathered}
$$

Recognizing that the first exponential term does not vary with $q$, we can define the relations:

$$
\begin{gathered}
C_{m n}=\sum_{q=0}^{V-1} c_{m n} \exp i\left[(n B-m) \Delta \theta_{q}\right] \\
\frac{C_{m n}}{c_{m n}}=\sum_{q=0}^{V-1} \exp i\left[(n B-m) \Delta \theta_{q}\right]
\end{gathered}
$$


Forming this quantity is important because it appears in the expression for the total acoustic power as described by Sofrin and Mathews (Ref. 1)

$$
W=\frac{1}{2 \rho a} \sum_{n=1}^{\infty} \sum_{m=-\infty}^{\infty} \sum_{\mu=-\infty}^{\infty} a_{m n \mu} C_{m n \mu} C_{m n \mu}^{*} A_{m n \mu}
$$

Neglecting radial variations of pressure, the "normalized" expected power is defined as

$$
\begin{gathered}
U=\sum_{n=1}^{\infty} \sum_{m=1}^{\infty} a_{m n}\left|\frac{C_{m n}}{c_{m n}}\right|^{2} \\
\left|\frac{C_{m n}}{c_{m n}}\right|^{2}=\left(\frac{C_{m n}}{c_{m n}}\right)\left(\frac{C_{m n}}{c_{m n}}\right)^{*}
\end{gathered}
$$

Sofrin and Mathews continue from this point to express this quantity in terms suitable for studying vanes whose angular positions deviate a small amount from a uniform spacing. Here, we will express this term in a general way suitable for representing the case of irregularly placed vanes.

$$
\left|\frac{C_{m n}}{c_{m n}}\right|^{2}=\sum_{q=0}^{V-1} \exp i(n B-m) \Delta \theta_{q} \sum_{j=0}^{V-1} \exp i(n B-m) \Delta \theta_{j}
$$

Defining the following two quantities can simplify the expression

$$
\begin{gathered}
\beta_{q}=(n B-m) \Delta \theta_{q} \\
\beta_{j}=(n B-m) \Delta \theta_{j} \\
\left|\frac{C_{m n}}{c_{m n}}\right|^{2}=\sum_{q=0}^{V-1} \exp \left(i \beta_{q}\right) \sum_{j=0}^{V-1} \exp \left(-i \beta_{j}\right)
\end{gathered}
$$

When $q=j$, the summation is equal to $V$ the number of vanes or pins, and when $q$ is not equal to $j$, the terms in the summation appear in complex conjugate pairs resulting in the following relation:

$$
\begin{gathered}
\left|\frac{C_{m n}}{c_{m n}}\right|^{2}=V+\sum_{j>q} \exp \left(i\left(\beta_{q}-\beta_{j}\right)\right)+\exp \left(-i\left(\beta_{q}-\beta_{j}\right)\right) \\
\left|\frac{C_{m n}}{c_{m n}}\right|^{2}=V+2 \sum_{j>q} \cos \left(\beta_{q}-\beta_{j}\right)=V+2 \sum_{j>q} \cos ((n B-m))\left(\left(\Delta \theta_{q}-\Delta \theta_{j}\right)\right)
\end{gathered}
$$


Values of this "Sofrin-Mathews power term," $\left|\frac{C_{m n}}{c_{m n}}\right|^{2}$, can be useful in predicting the circumferential modes generated by a rotor interacting with vanes with irregular circumferential spacing. The maximum and minimum values for this quantity are

$$
\left|\frac{C_{m n}}{c_{m n}}\right|^{2}=\left\{\begin{array}{c}
V+2 \sum_{q=0}^{V-1} q \\
0
\end{array}\right.
$$

The maximum value occurs when the cosine is equal to 1 for all of the terms in the summation which happens when $(n B-m)$ is an integer multiple of $V$. The minimum value occurs through cancellation of terms in the summation.

\section{Comparison of Measurements and Predictions}

The spectra at $2000 \mathrm{rpm}$ from the farfield microphone at $35^{\circ}$ are shown in Figure 5 for all configurations tested. A time history of acoustic pressure was acquired from each of the farfield microphones. Since this data is recorded synchronously with rotor shaft speed, tones at harmonics of blade passing frequency can be calculated precisely. Sound power levels (PWL) are calculated by squaring the sound pressure levels (SPL), multiplying by the appropriate area, then normalizing by the specific acoustic impedance.

It is important to realize that the total sound power levels computed from the farfield microphone arrays include noise not synchronous with the shaft speed. In these tests, noise produced by Strouhal shedding downstream of the rods is clearly visible on the spectra, and included in the total sound power levels as computed from the farfield microphone arrays. While the spectra do show that Strouhal shedding from the rods contributes to the total noise produced $(\mathrm{St} \approx 0.2, f=128 \mathrm{~Hz}$ ), the dominant source of noise is still attributed to the rotor-rod interaction that generates tones at the harmonics of blade passing frequency.

Tones at harmonics of blade passing frequency (BPF) are evident in Figure 5 even for the baseline configuration without any rods (Configuration 5). The directivity plots of Figure 6 confirm that the amplitude of the tones for the baseline configuration are indeed lower than those for all the rod configurations tested at all angles. This allows us to isolate the effects of the various rod placements. The source of the tones for the baseline configuration (rotor alone, no rods or stators) is not presently well understood and is currently an area of investigation.

For Configuration 1 (6 evenly spaced rods), the amplitude of the sound power level of the tone at blade passing frequency decreases as the harmonic index increases. This trend is not displayed for the asymmetric cases tested at farfield angle of $35^{\circ}$. If we examine the trends in the 1-BPF tone at the farfield angle of $35^{\circ}$, we see that the amplitude of this tone is greatest for Configuration 4 (8 asymmetric rods), followed by Configuration 1 ( 6 equally spaced rods), Configuration 2 ( 6 rods, $12^{\circ}$ apart), and then Configuration 3 ( 15 rods, $12^{\circ}$ apart).

The directivity plots for the tones at 1-BPF, 2-BPF and 3-BPF are given in Figure 6. The directivity plots show the trends in the sound pressure levels of the tones as angular location varies. The trends in the 1-BPF tone seen in the spectra at the farfield angle of $35^{\circ}$ for the asymmetric cases are consistent at all microphone locations, though the trends in the 1-BPF tone for Configuration 1 shows some angular variation, particularly in the aft array. The trends seen for the 2-BPF and 3-BPF tones seen in the spectra at the $35^{\circ}$ farfield microphone location are not seen consistently at all angles in the directivity plots of Figure 6. 
Figures 7 and 8 show the measured and predicted circumferential mode sound power levels (PWL). The reader is reminded that the predictions are not true power levels, but are simply an apparent dominant term in the sound power equation. To facilitate comparison of trends, all of the predicted values shown are anchored to the 1-BPF measured tone for Configuration 1, and scaled in the following way:

$$
d B\left(\left|\frac{C_{m n}}{c_{m n}}\right|^{2}\right)_{\text {scaled }}=10 \log _{10}\left(\frac{\left|C_{m n} / c_{m n}\right|^{2}}{36}\right)+121.3
$$

where $121.3 \mathrm{~dB}$ is the sound power level measured for the 1-BPF Configuration 1 (6 equally spaced rods) and 36 is the value of the predicted power term for the 1-BPF Configuration 1 for mode number -2 .

Changes in the sound power levels of the 1-BPF and 2-BPF tones between the various configurations can also be calculated from the measurements and predictions, as shown in Table 5. All asymmetric configurations were compared to Configuration 1 ( 6 equally spaced rods). The good agreement seen between the predicted and measured deltas is attributed to the apparent little change in the value of $a_{m n}$ in Equation (12) as the number of rods was varied for a single operating condition. The predicted changes in sound power level for the 1-BPF tone are closest to the difference calculated from the Inlet Rotating Rake measurements, while the 2-BPF predicted changes are closest to the differences calculated from the entire Farfield Array. The predicted changes in sound power level were calculated using the following relation:

$$
\Delta P W L_{\text {predicted }, n}=10 * \log _{10}\left\{\frac{\left[\sum_{m}\left|\frac{C_{m n}}{c_{m n}}\right|^{2}\right]}{\left[\sum_{m}\left|\frac{C_{m n}}{c_{m n}}\right|^{2}\right]_{\text {Configuration } 1}}\right\}
$$

\begin{tabular}{|c|c|c|c|c|}
\hline Configurations compared & $\begin{array}{l}\text { Inlet rotating rake, } \\
\mathrm{dB}\end{array}$ & $\begin{array}{c}\text { Exhaust rotating rake, } \\
\mathrm{dB}\end{array}$ & $\begin{array}{l}\text { Farfield array, } \\
\text { dB }\end{array}$ & $\begin{array}{c}\text { Predictions, } \\
\text { dB }\end{array}$ \\
\hline \multicolumn{5}{|c|}{$1 \mathrm{BPF}$} \\
\hline $\mathrm{C} 2-\mathrm{C} 1$ & -12.6 & -12.3 & -10.5 & -11.5 \\
\hline $\mathrm{C} 3-\mathrm{C} 1$ & -12.0 & -8.0 & -18.0 & -12.3 \\
\hline $\mathrm{C} 4-\mathrm{C} 1$ & -3.5 & -3.8 & 0.5 & -3.5 \\
\hline \multicolumn{5}{|c|}{$2 \mathrm{BPF}$} \\
\hline $\mathrm{C} 2-\mathrm{C} 1$ & 0.1 & -2.8 & -0.9 & 0.9 \\
\hline $\mathrm{C} 3-\mathrm{C} 1$ & 8.4 & 6.23 & 5.9 & 4.9 \\
\hline $\mathrm{C} 4-\mathrm{C} 1$ & -5.0 & 0.8 & 1.5 & 1.5 \\
\hline
\end{tabular}

TABLE 5.-A COMPARISON OF PREDICTED AND MEASURED CHANGES IN SOUND POWER LEVELS

\section{Conclusion}

Fan inflow distortion tone noise was studied experimentally and analytically. Cylindrical rods inserted radially into the duct distorted the flow entering the fan. The rods were arranged in four circumferentially asymmetric patterns. Farfield and in-duct acoustic pressure measurements were recorded. An analytic description of acoustic pressure resulting from the interaction of a rotor and an asymmetric stator was presented to represent the highly asymmetric configurations tested. Trends in circumferential mode power levels were predicted and shown to be in good agreement with measurements. This predictive capability is a beginning step in developing tools to estimate the mode power levels produced by fans ingesting distorted inflow, an area of concern for those developing aircraft with embedded engines. 


\section{References}

1. Sofrin, T.G. and Mathews, D.C., "Asymmetric Stator Interaction Noise,” J. of Aircraft, Vol. 17, No. 8, 1979, pp. 554-560.

2. FAA, "FAA Aerospace Forecast Fiscal Years 2008-2025," FAA HQ-027907.qxd, 2008.

3. Donohue, George L., Shaver III, Russel D., Edwards, Eric (eds.), Terminal Chaos, American Institute of Aeronautics and Astronautics, New York, 2008.

4. Bridges, J.E., Envia, E. and Huff, D., "Recent Developments in U.S. Engine Noise Reduction Research,” NASA/TM-2001-211083, 2001.

5. Hall, C.A. and Crichton, D., "Engine and Installation Configurations for a Silent Aircraft," ISABE2005-1164, 2005.

6. Cooper, B., "A Large Hemi-Anechoic Enclosure for Community-Compatible Aeroacoustic Testing of Aircraft Propulsion Systems,” NASA TM-106015, 1993.

7. Loew, R.A., Lauer, J.T., McAllister, J. and Sutliff, D.L., "The Advanced Noise Control Fan," NASA/TM-2006-214368, 2006.

8. Langford, M.D., Minton, C., Ng, W.F., Burdisso, R.A. and Halasz, C., "Fan Flow Control for Noise Reduction Part 3: Rig Testing of Optimal Design," AIAA-2005-3027, 2005.

9. Sutliff, D.L., "Rotating Rake Turbofan Duct Mode Measurement System," NASA/TM-2005213828, 2005.

10. Tyler, J.M. and Sofrin, T.G., "Axial Flow Compressor Noise Studies,” Journal of Aircraft, Vol. 70, No. 8, 1962, pp. 309-332. 


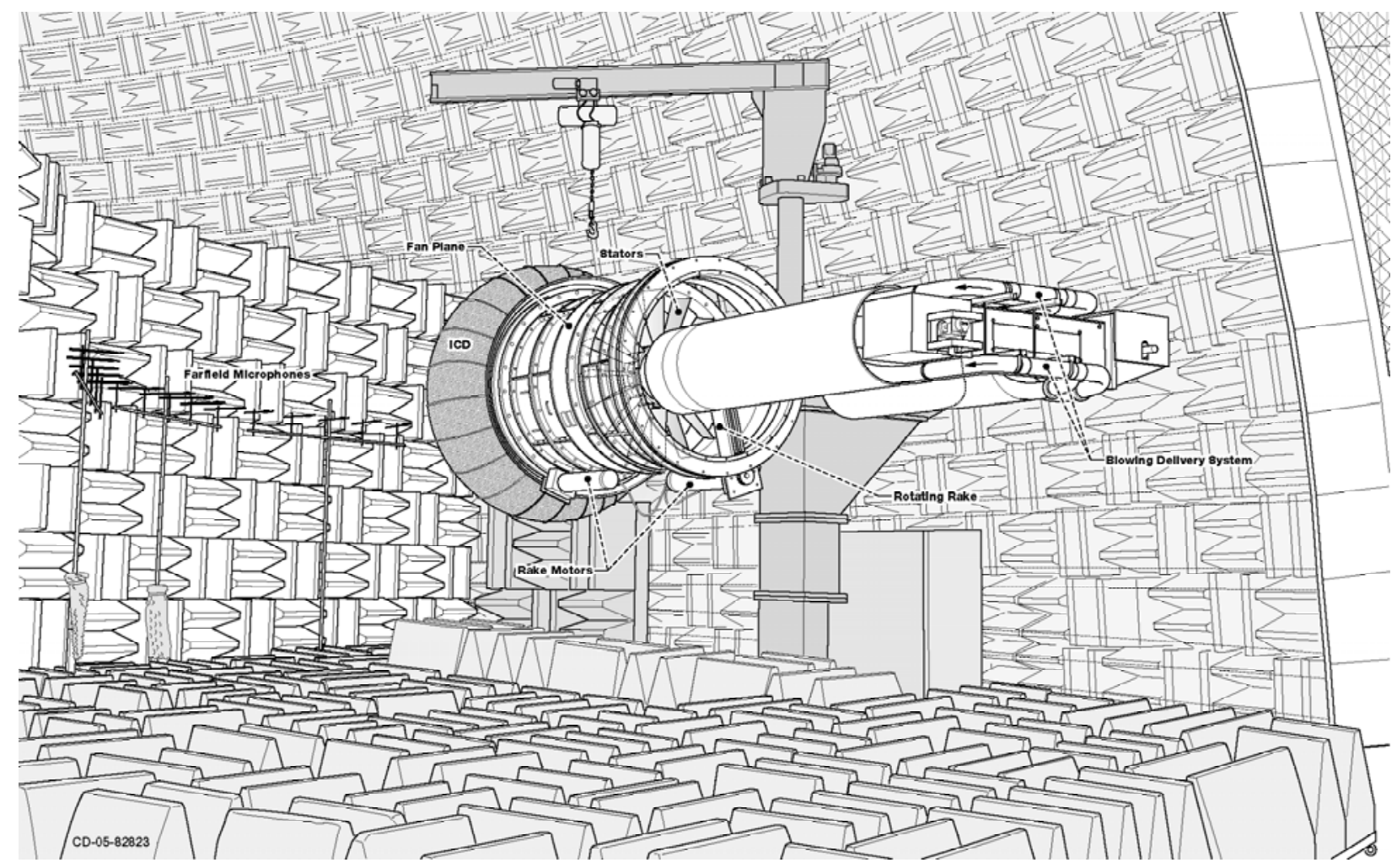

Figure 1.- The Advanced Noise Control Fan Rig in the NASA Glenn AeroAcoustic Propulsion Lab.

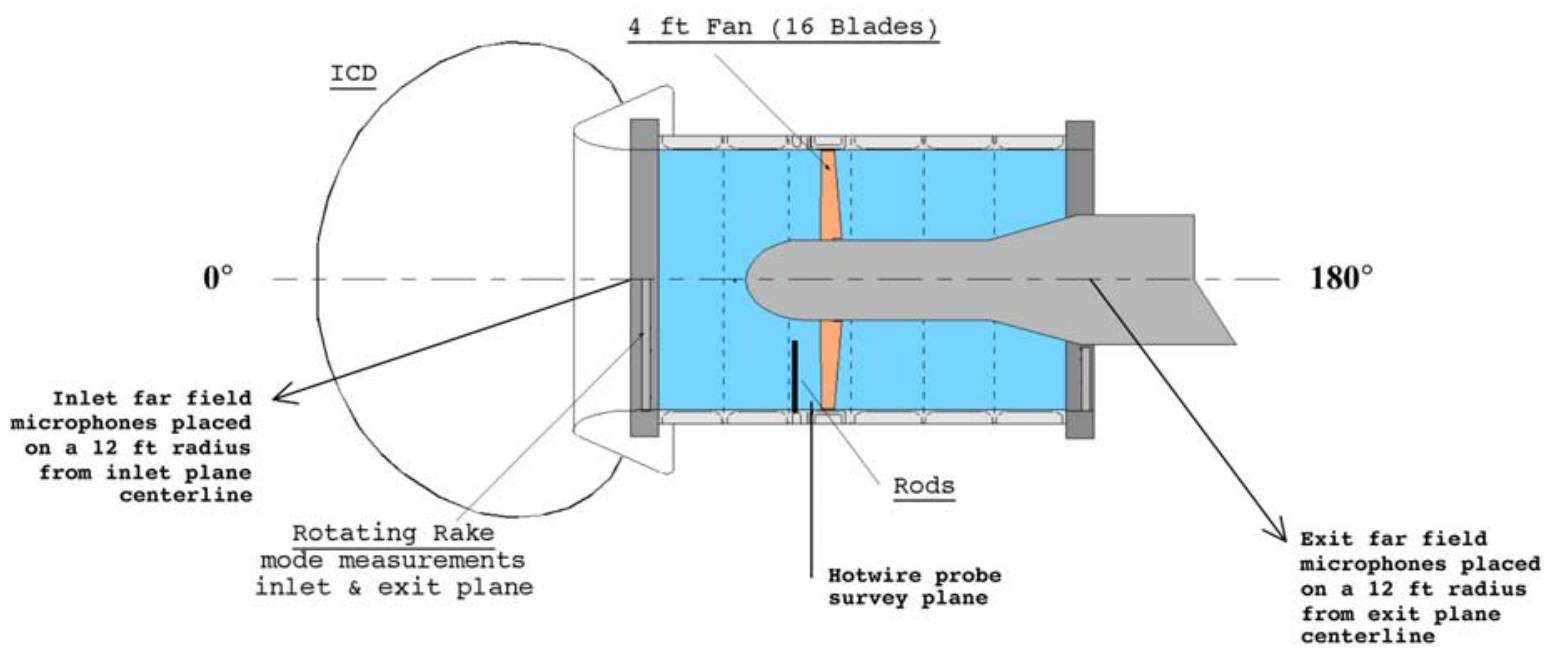

Figure 2.-Cross-sectional diagram of Advanced Noise Control Fan for the Inlet Distortion Tests. 


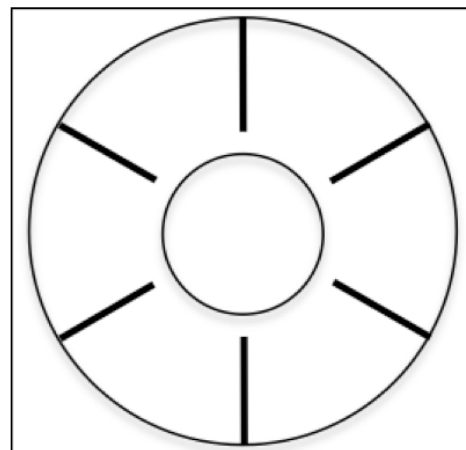

Configuration 1

6 equally spaced rods

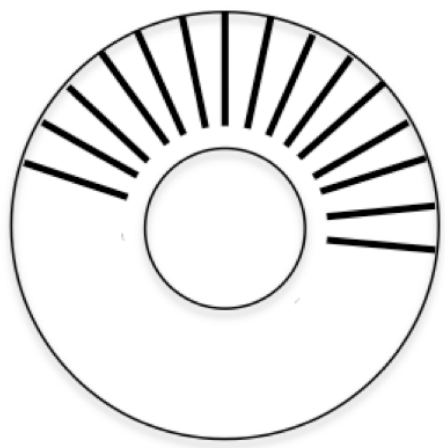

Configuration 3 15 rods $12^{\circ}$ apart

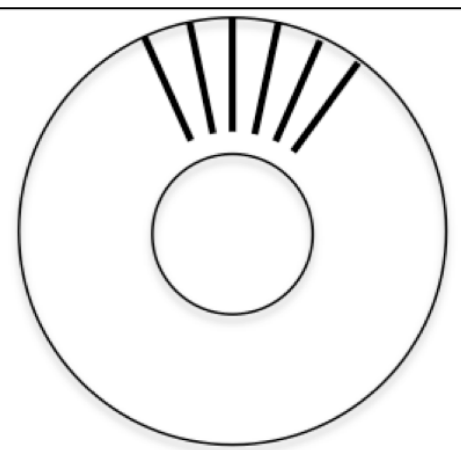

Configuration 2

6 rods $12^{\circ}$ apart

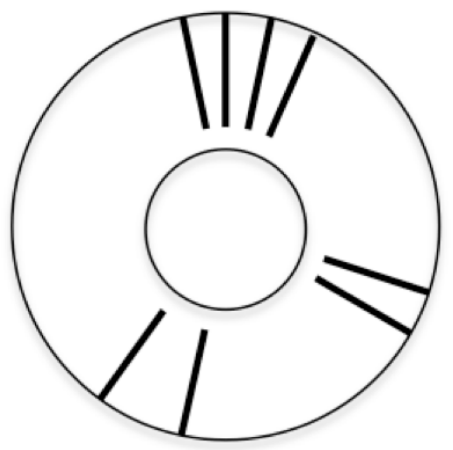

Configuration 4

8 rods integer multiples of $12^{\circ}$

Figure 3.-Circumferential Locations of Rods Tested.

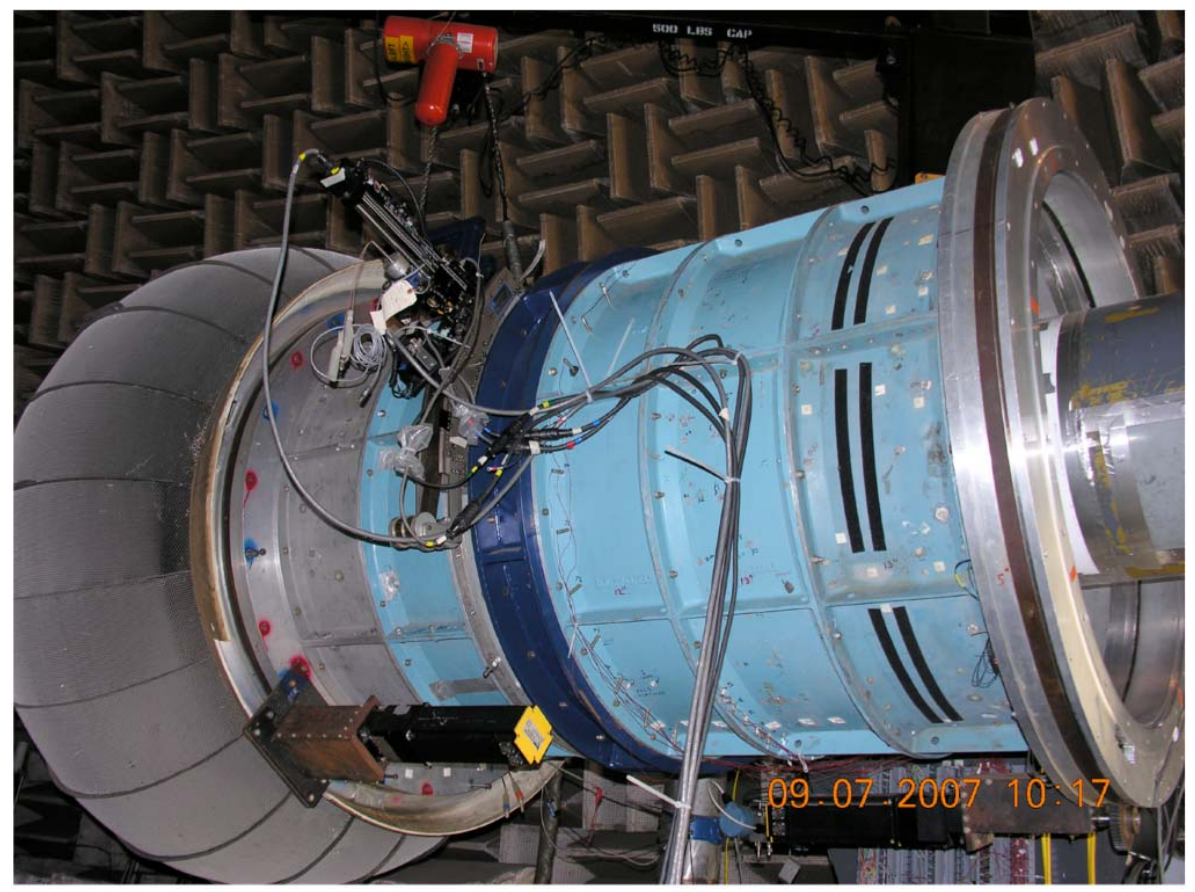

Figure 4.-Photograph of Advanced Noise Control Fan Rig. 

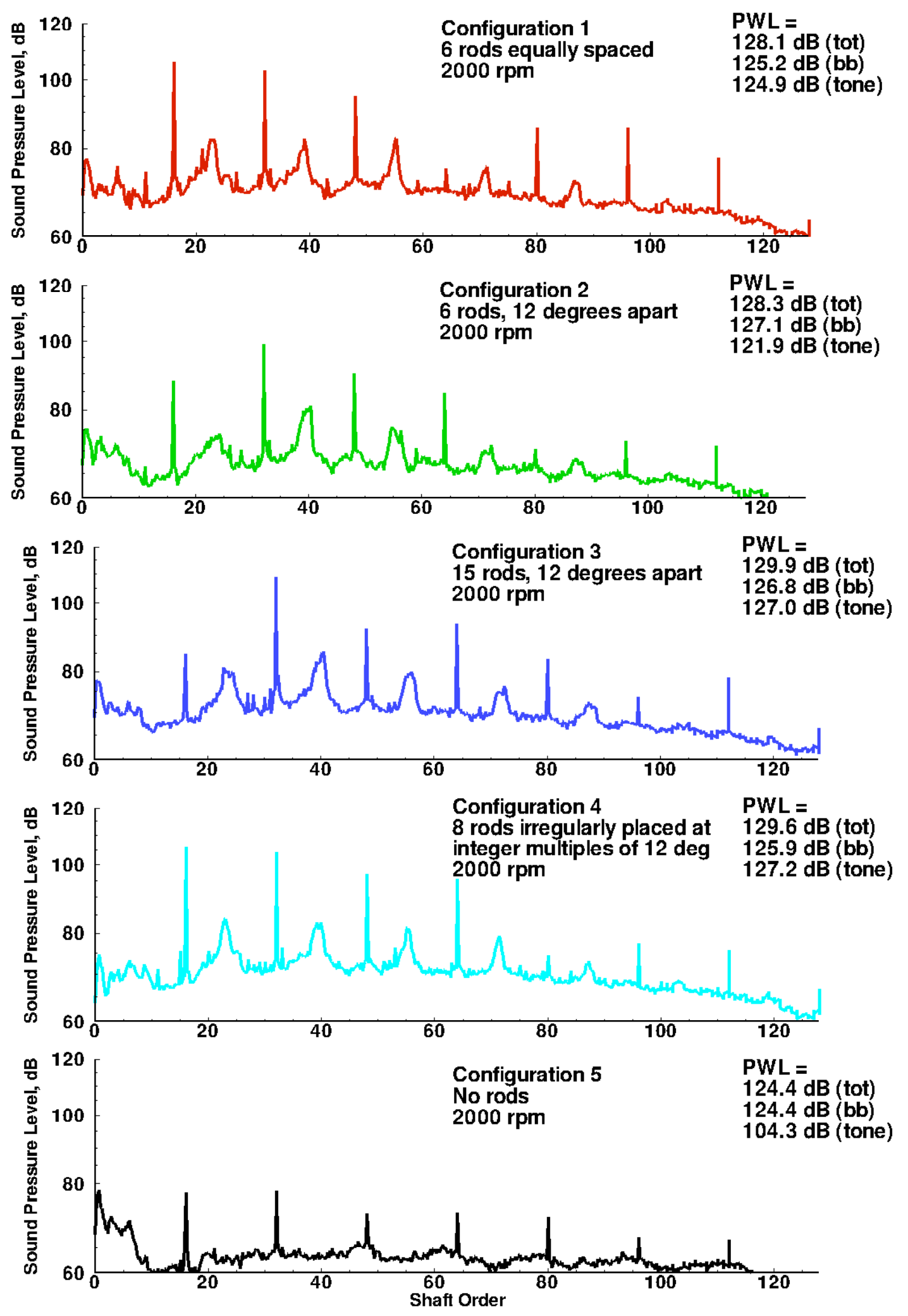

Figure 5.-Spectra from Farfield Microphone at $35^{\circ}$ in the Inlet Array. 

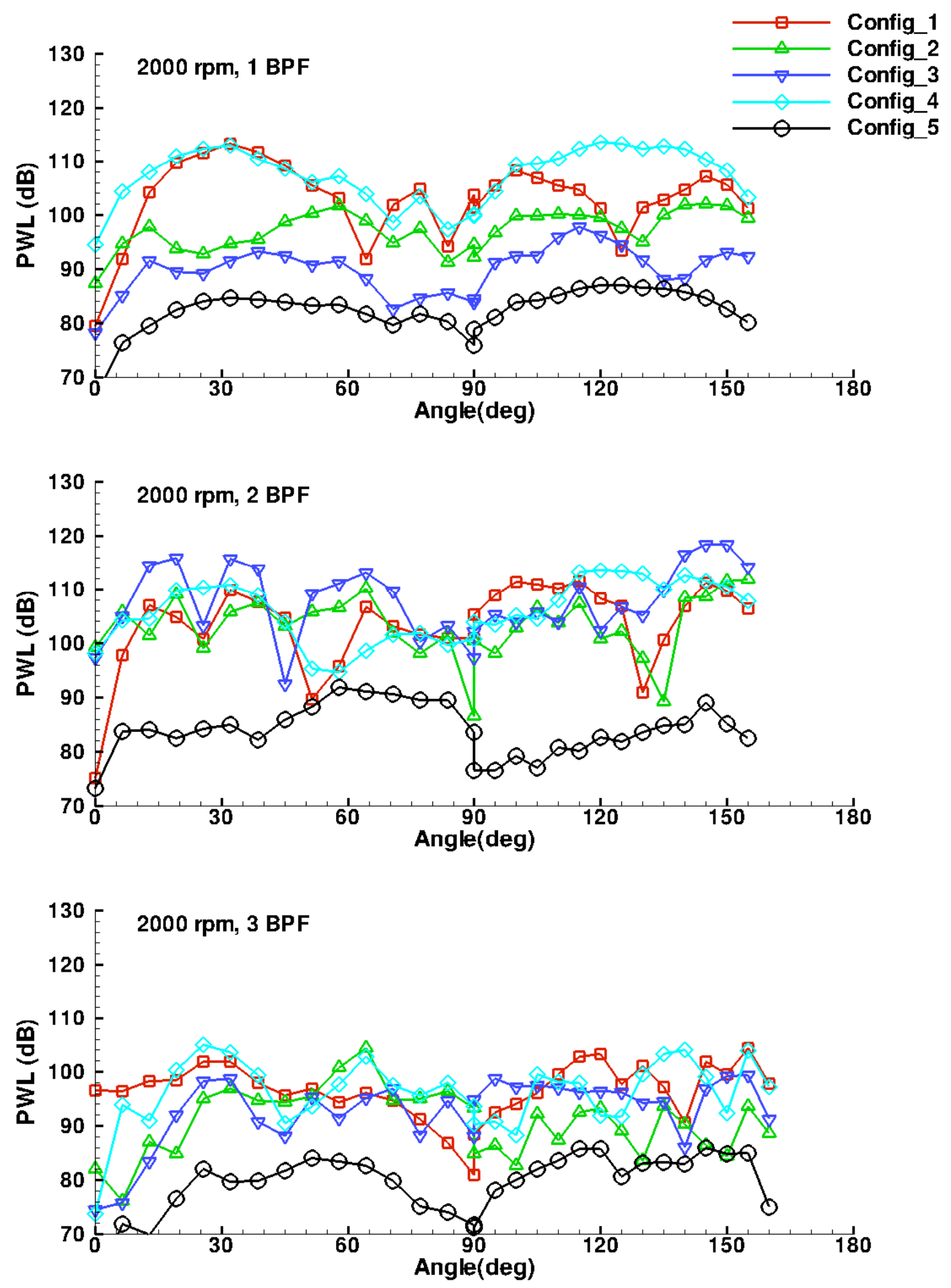

Figure 6.-Directivity Plots from the Farfield Microphone Arrays. 

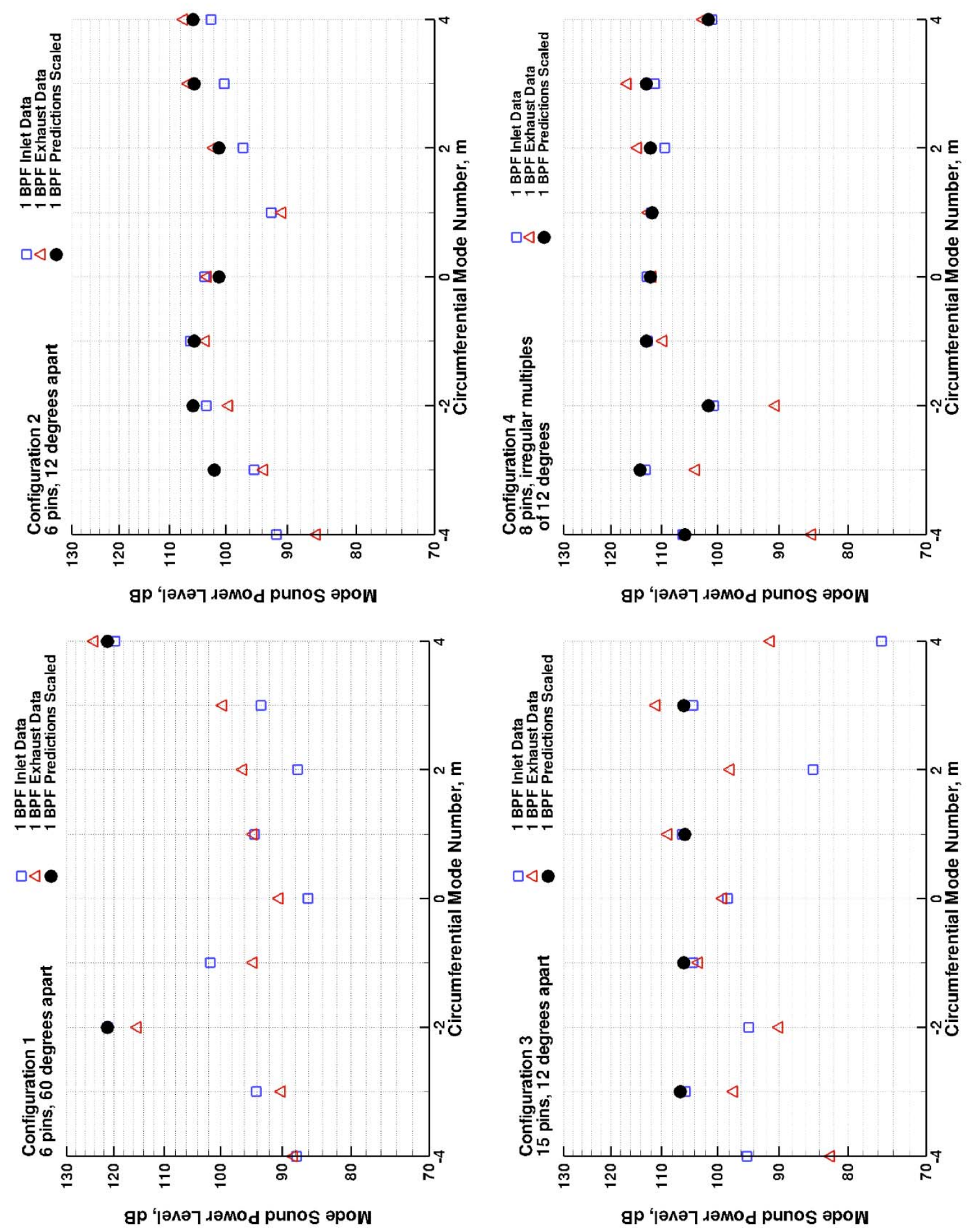

Figure 7.-Measured and Predicted In-duct Circumferential Mode Power Levels-I-BPF. 

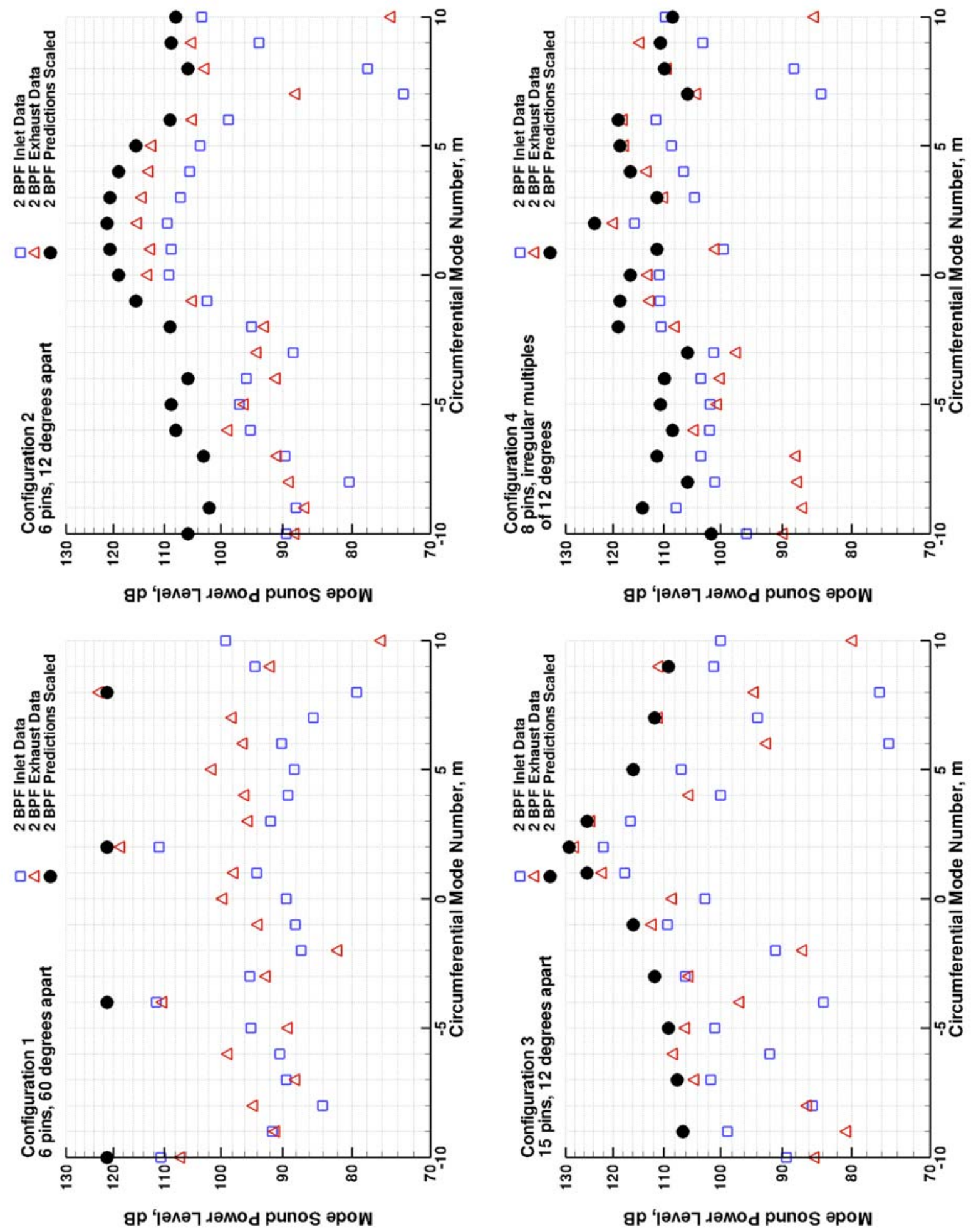

Figure 8.--Measured and Predicted In-duct Circumferential Mode Power Levels-2-BPF. 


\begin{tabular}{|c|c|c|}
\hline \multicolumn{2}{|c|}{ REPORT DOCUMENTATION PAGE } & $\begin{array}{c}\text { Form Approved } \\
\text { OMB No. 0704-0188 }\end{array}$ \\
\hline \multicolumn{3}{|c|}{ 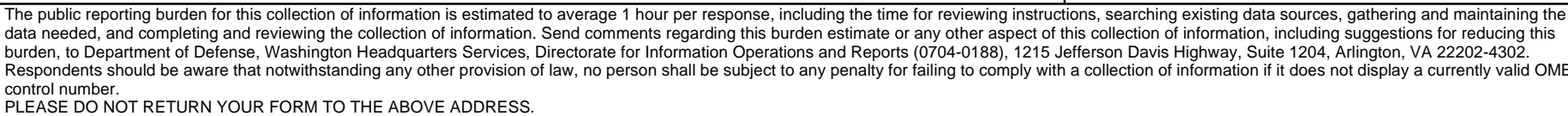 } \\
\hline $\begin{array}{l}\text { 1. REPORT DATE (DD-MM-YYYY) } \\
01-01-2010\end{array}$ & $\begin{array}{l}\text { 2. REPORT TYPE } \\
\text { Technical Memorandum }\end{array}$ & 3. DATES COVERED (From - To) \\
\hline \multirow{3}{*}{\multicolumn{2}{|c|}{$\begin{array}{l}\text { 4. TITLE AND SUBTITLE } \\
\text { An Experimental Study of Fan Inflow Distortion Tone Noise }\end{array}$}} & 5a. CONTRACT NUMBER \\
\hline & & 5b. GRANT NUMBER \\
\hline & & 5c. PROGRAM ELEMENT NUMBER \\
\hline \multirow{3}{*}{\multicolumn{2}{|c|}{$\begin{array}{l}\text { 6. AUTHOR(S) } \\
\text { Koch, L., Danielle }\end{array}$}} & 5d. PROJECT NUMBER \\
\hline & & 5e. TASK NUMBER \\
\hline & & $\begin{array}{l}\text { 5f. WORK UNIT NUMBER } \\
\text { WBS 561581.02.08.03.18.03 }\end{array}$ \\
\hline \multicolumn{2}{|c|}{$\begin{array}{l}\text { 7. PERFORMING ORGANIZATION NAME(S) AND ADDRESS(ES) } \\
\text { National Aeronautics and Space Administration } \\
\text { John H. Glenn Research Center at Lewis Field } \\
\text { Cleveland, Ohio 44135-3191 }\end{array}$} & $\begin{array}{l}\text { 8. PERFORMING ORGANIZATION } \\
\text { REPORT NUMBER } \\
\text { E-17106 }\end{array}$ \\
\hline \multirow{2}{*}{\multicolumn{2}{|c|}{$\begin{array}{l}\text { 9. SPONSORING/MONITORING AGENCY NAME(S) AND ADDRESS(ES) } \\
\text { National Aeronautics and Space Administration } \\
\text { Washington, DC 20546-0001 }\end{array}$}} & $\begin{array}{l}\text { 10. SPONSORING/MONITOR'S } \\
\text { ACRONYM(S) } \\
\text { NASA }\end{array}$ \\
\hline & & $\begin{array}{l}\text { 11. SPONSORING/MONITORING } \\
\text { REPORT NUMBER } \\
\text { NASA/TM-2010-215844; AIAA-2009- } \\
3290\end{array}$ \\
\hline \multicolumn{3}{|c|}{$\begin{array}{l}\text { 12. DISTRIBUTIONIAVAILABILITY STATEMENT } \\
\text { Unclassified-Unlimited } \\
\text { Subject Categories: } 02 \text { and } 71 \\
\text { Available electronically at http://gltrs.grc.nasa.gov } \\
\text { This publication is available from the NASA Center for AeroSpace Information, 443-757-5802 }\end{array}$} \\
\hline
\end{tabular}

\section{SUPPLEMENTARY NOTES}

\section{ABSTRACT}

The tone noise generated when a fan ingests circumferentially distorted flow was studied by an experiment conducted with the Advanced Noise Control Fan at the NASA Glenn Research Center. The inflow was distorted by inserting cylindrical rods radially into the duct. The rods were arranged in circumferentially irregular patterns in three of the five configurations tested. Rods were held in place using a mounting ring with 30 equally spaced holes placed at an axial location one rotor chordlength upstream of the fan. Acoustic pressure was measured in the inlet and exhaust duct of the fan using the Rotating Rake fan tone measurement system. Sound power levels, calculated from the measured data, were plotted as a function of circumferential mode. An analytic description of the unsteady pressure distribution at the interaction plane between the stationary rods and the fan rotor is presented in a form suitable for representing the circumferentially irregularly placed rods. Terms in the analytical description for sound power were proven to be useful in determining the dominant circumferential modes measured in the experiment and the differences in mode power level between the configurations tested. Insight gained through this work will be useful in the development of tools to compute fan inflow distortion tone noise.

\section{SUBJECT TERMS}

Ducted fans; Noise

\begin{tabular}{|c|c|c|c|c|c|}
\hline \multicolumn{3}{|c|}{ 16. SECURITY CLASSIFICATION OF: } & \multirow{2}{*}{$\begin{array}{l}\text { 17. LIMITATION OF } \\
\text { ABSTRACT } \\
\text { UU }\end{array}$} & \multirow{2}{*}{$\begin{array}{l}\text { 18. NUMBER } \\
\text { OF } \\
\text { PAGES } \\
21\end{array}$} & \multirow{2}{*}{$\begin{array}{l}\text { 19a. NAME OF RESPONSIBLE PERSON } \\
\text { STI Help Desk (email:help@sti.nasa.gov) } \\
\text { 19b. TELEPHONE NUMBER (include area code) } \\
\text { 443-757-5802 }\end{array}$} \\
\hline $\begin{array}{l}\text { a. REPORT } \\
\mathrm{U}\end{array}$ & $\begin{array}{l}\text { b. ABSTRACT } \\
\mathrm{U}\end{array}$ & $\begin{array}{l}\text { c. THIS } \\
\text { PAGE } \\
\text { U }\end{array}$ & & & \\
\hline
\end{tabular}



